\title{
Vinasse Effect on Herbicides Clomazone and Tebuthiuron Availability In Different KIndS OF SoIls ${ }^{1}$
}

\author{
Efeito da Vinhaça na Disponibilidade dos Herbicidas Clomazone e Tebuthiuron em Diferentes \\ Solos
MATOS, A.K.A. ${ }^{2}$, CARBONARI, C.A. ${ }^{2}$, VELINI, E.D. ${ }^{2}$, GOMES, G.L.G.C. ${ }^{2}$, TRINDADE, M.L.B. ${ }^{3}$, and MACEDO, G.C. ${ }^{2}$

\begin{abstract}
The objective of this study was to evaluate the availability of herbicides clomazone and tebuthiuron in the solution in different kinds of soils saturated with water or vinasse. Samples of 30 soils with different characteristics were arranged on trays to the herbicides spraying. Then they were homogenized, placed in plastic cartridges and saturated with deionized water or vinasse, and remaining at rest during 18 hours. Two extractions were made, the first one quantified the presence of the herbicides in the soil solution and in the second one the total extraction of herbicide remaining in the soil was taken to determine the recovery percentage of each herbicide tested. For quantification, a LC-MS/MS system was used, a compound of a high performance liquid chromatograph (HPLC) coupled to a triple quadruple mass spectrometer. Tebuthiuron was more available in the soil with the vinasse addition when compared to water. Vinasse applications resulted in no significant difference in availability of clomazone between treatments. Tebuthiuron showed the highest availability frequencies, and on average of all samples $32.49 \%$ were extracted from total herbicide applied, while for clomazone this value was $16.50 \%$.
\end{abstract}

Keywords: sugarcane, mass spectrometry, HPLC, sorption.

RESUMO - O objetivo deste estudo foi avaliar a disponibilidade dos herbicidas clomazone e tebuthiuron na solução de diferentes solos saturados com água ou vinhaça. Amostras de 30 solos com caracteristicas distintas foram dispostas em bandejas para a pulverização dos herbicidas. Em seguida, foram homogeneizadas, acondicionadas em cartuchos plásticos e saturadas com água deionizada ou vinhaça, permanecendo em repouso durante 18 horas. Foram feitas duas extrações: na primeira, quantificaram-se os herbicidas presentes na solução do solo e, na segunda, extraiu-se o total de herbicida remanescente no solo para determinação da porcentagem de recuperação de cada herbicida testado. Nas quantificações utilizou-se um sistema LC-MS/MS, composto por um cromatógrafo liquido de alta eficiência (CLAE) acoplado a um espectrômetro de massas triplo quadrupolo. O tebuthiuron esteve mais disponivel nos solos com a adição de vinhaça, quando comparado com a água. Aplicações de vinhaça não resultaram em diferença significativa na disponibilidade do clomazone entre os tratamentos. O tebuthiuron apresentou maiores frequências de disponibilidade, tendo sido extraidos em média 32,49\% do total do herbicida aplicado, enquanto para o clomazone esse valor foi de 16,50\%.

Palavras-chave: cana-de-açúcar, espectrometria de massas, CLAE, sorção.

\section{INTRODUCTION}

In Brazil there are about 40 molecules of herbicides registered for use in the culture of sugarcane, which were described by the
Phytosanitary Pesticides System (Sistema de Agrotóxicos Fitossanitários) (Brasil, 2015). Most herbicides are recommended for application in preemergence just after harvesting (Blanco et al., 2010); among the

1 Recebido para publicação em 20.6.2015 e aprovado em 7.7.2015.

2 Universidade Estadual Paulista “Júlio de Mesquita Filho” (UNESP), Botucatu-SP, Brasil, <karollynamatos1991@gmail.com>; ${ }^{3}$ Bioativa Pesquisa e Compostos Bioativos, Botucatu-SP, Brasil. 
products used are clomazone and tebuthiuron, which are used to control monocotyledonous and dicotyledonous weeds.

Clomazone is a nonionic herbicide that exhibits low sorption capacity in the soil $\left(\mathrm{K}_{\mathrm{d}}=0.47-5.30 \mathrm{~mL} \mathrm{~g}^{-1}\right)$, due to high water solubility $\left(1,100 \mathrm{~g} \mathrm{~L}^{-1}\right)$ and high vapor pressure of $1.92 \times 10^{-2} \mathrm{~Pa}$ at $25^{\circ} \mathrm{C}$ (Rodrigues \& Almeida, 2011). When applied in an aerobic medium, the half-life of clomazone is 47.3 days, but in anaerobic conditions it is 7.9 days (Tomco et al., 2010).

Tebuthiuron has, as main features, high water solubility $\left(2.570 \mathrm{mg} \mathrm{L}^{-1}\right.$ at $\left.20^{\circ} \mathrm{C}\right)$, vapor pressure $=2.7 \times 10^{-4} \mathrm{~Pa}$ at $25^{\circ} \mathrm{C}$ and low coefficient of sorption $\left(\mathrm{K}_{\mathrm{d}}=0.071 .65 \mathrm{~L} \mathrm{~kg}^{-1}\right)$ (Rodrigues \& Almeida, 2011; Tonieto \& Regitano, 2014). These properties give it low sorption capacity to soil colloids and is considered a product with a high potential for leaching (Matallo et al., 2005). However, when applied in soils with higher organic matter content, it may have a half-life of up to 486 days (Helbert, 1990).

Regardless of the target or application mode, the herbicides final destination is the soil. When they reach the ground, they are subject to retention, transformation and transportation processes, as well as the interaction among them (Spadotto et al., 2003). The molecules dynamics in the soil depends on a complex variety of chemical, physical and biological processes including sorption, volatilization, leaching and chemical and/or microbial degradation (Arias-Estévez et al., 2008).

Among these processes, sorption plays a key role in regulating the transport, degradation, persistence and bioaccumulation in the soil, due to reduced availability in the solution and herbicide movement restriction in the soil matrix (De Jonge et al., 1996; Boivin et al., 2005). Sorption depends on the physicochemical properties of the herbicide, and especially the content and composition of organic matter in the soil (Benoit et al., 2008; Tian et al., 2010; El-Nahhal et al., 2013).

Vinasse, a residue from the sugar-alcohol industry applied to the soil in fertigation of reeds, has a high content of dissolved organic matter, ranging from 10,973 and $14,801 \mathrm{mg} \mathrm{L}^{-1}$ (Benke et al., 1999), and a high capacity of proton donation (Parnaudeau et al., 2008). The incorporation of vinasse to the soil may increase the amount of dissolved organic carbon and change the cations saturation in the soil solution, which directly or indirectly affects the sorption mechanisms (FernándezBayo, 2009). However, there is little information on vinasse effects on sorption and availability of herbicides used in the cultivation of sugarcane.

Understanding the processes involved in the herbicides dynamics in the soil allows more precise recommendations regarding the doses to be applied, which can be adjusted according to the molecules availability in the soil solution. Thus, there is more movement and persistence extension predictability of herbicides, resulting in the opportunity to reduce production costs and environmental contamination risks.

Based on this assumption, this study objective was to evaluate the effects of water or vinasse application on the availability of clomazone and tebuthiuron herbicides in the solution of different soils.

\section{MATERIALS AND METHODS}

\section{Treatments and applications of herbicides}

The experiments were conducted in a laboratory, performing applications of herbicides clomazone (Gamit 500) at 1,400 g a.i. ha ${ }^{-1}$ and tebuthiuron (Combine $500 \mathrm{SC}$ ) at 1,200 g a.i. ha-1 in 30 types of soils with different textural classes and chemical characteristics (Table 1).

After the application of herbicides, for each soil type two treatments were tested, with the soil saturation with deionized water or vinasse. The experiment was conducted in a completely randomized design with three replications

The different soils were individually distributed in a $2 \mathrm{~cm}$ deep uniform layer in plastic containers with an area equal to $110.25 \mathrm{~cm}^{2}$. In the application of herbicides, a stationary spray was used in a controlled environment (laboratory), equipped with a 
Table 1 - Results of chemical and granulometric analysis of the soil samples used in the experiment

\begin{tabular}{|c|c|c|c|c|c|c|c|}
\hline \multirow{2}{*}{ Soil } & \multirow{2}{*}{$\frac{\mathrm{pH}}{\left(\mathrm{CaCl}_{2}\right)}$} & \multirow{2}{*}{$\begin{array}{c}\text { M.O. } \\
\left(\mathrm{g} \mathrm{dm}^{-3}\right)\end{array}$} & \multirow{2}{*}{$\begin{array}{c}\text { CTC } \\
\left(\mathrm{mmol}_{\mathrm{c}} \mathrm{dm}^{3}\right)\end{array}$} & \multicolumn{3}{|c|}{ Granulometry g kg $^{-1}$} & \multirow{2}{*}{ Soil texture } \\
\hline & & & & Sand & Clay & Silt & \\
\hline 1 & 3.8 & 36 & 125 & 671 & 215 & 114 & mean \\
\hline 2 & 3.8 & 38 & 145 & 675 & 295 & 30 & mean \\
\hline 3 & 4.0 & 36 & 105 & 712 & 247 & 41 & mean \\
\hline 4 & 3.8 & 34 & 119 & 704 & 242 & 54 & mean \\
\hline 5 & 3.9 & 39 & 137 & 636 & 308 & 56 & mean \\
\hline 6 & 3.9 & 35 & 131 & 656 & 186 & 158 & mean \\
\hline 7 & 3.8 & 34 & 137 & 712 & 231 & 57 & mean \\
\hline 8 & 3.9 & 37 & 131 & 663 & 272 & 65 & mean \\
\hline 9 & 3.8 & 39 & 148 & 584 & 340 & 76 & mean \\
\hline 10 & 4.0 & 37 & 138 & 561 & 338 & 101 & mean \\
\hline 11 & 4.0 & 34 & 124 & 763 & 138 & 99 & sandy \\
\hline 12 & 3.8 & 33 & 132 & 754 & 200 & 46 & mean \\
\hline 13 & 3.9 & 33 & 114 & 751 & 200 & 49 & mean \\
\hline 14 & 3.9 & 35 & 139 & 704 & 182 & 114 & mean \\
\hline 15 & 4.0 & 27 & 126 & 789 & 148 & 63 & sandy \\
\hline 16 & 3.9 & 31 & 137 & 723 & 22 & 55 & mean \\
\hline 17 & 3.9 & 30 & 133 & 742 & 201 & 57 & mean \\
\hline 18 & 3.9 & 29 & 132 & 734 & 218 & 48 & mean \\
\hline 19 & 3.9 & 30 & 117 & 747 & 197 & 56 & mean \\
\hline 20 & 3.8 & 46 & 141 & 636 & 301 & 63 & mean \\
\hline 21 & 4.0 & 39 & 145 & 481 & 386 & 133 & clayey \\
\hline 22 & 4.1 & 25 & 96 & 658 & 247 & 95 & mean \\
\hline 23 & 4.8 & 15 & 51 & 885 & 97 & 18 & sandy \\
\hline 24 & 3.9 & 13 & 52 & 875 & 101 & 24 & sandy \\
\hline 25 & 4.0 & 12 & 39 & 906 & 63 & 31 & sandy \\
\hline 26 & 4.1 & 9 & 33 & 890 & 69 & 41 & sandy \\
\hline 27 & 4.0 & 9 & 43 & 884 & 74 & 42 & sandy \\
\hline 28 & 4.4 & 15 & 60 & 854 & 119 & 27 & sandy \\
\hline 29 & 5.0 & 11 & 42 & 900 & 77 & 23 & sandy \\
\hline 30 & 4.1 & 43 & 118 & 557 & 355 & 88 & clayey \\
\hline
\end{tabular}

spray boom with four XR 11002 VS nozzles, spaced $0.5 \mathrm{~m}$ apart and arranged at $0.5 \mathrm{~m}$ height from the container containing the soils. The operating pressure used for the equipment was $2.0 \mathrm{kgf} \mathrm{cm}^{-2}$, with a controlled speed of $3.6 \mathrm{~km} \mathrm{~h}^{-1}$ and spray mix consumption of $200 \mathrm{~L} \mathrm{ha}^{-1}$. At the time of application the temperature was $22.1^{\circ} \mathrm{C}$, with relative humidity of $72 \%$.

The vinasse used in the experiments was collected in a sugarcane processing unit and had the following physical and chemical characteristics: $\mathrm{P}_{2} \mathrm{O}_{5}\left(\mathrm{~g} \mathrm{~L}^{-1}\right), 0.1 ; \mathrm{K}_{2} \mathrm{O}\left(\mathrm{g} \mathrm{L}^{-1}\right), 5.1$; $\mathrm{Ca}\left(\mathrm{g} \mathrm{L}^{-1}\right), 1.0 ; \mathrm{Mg}\left(\mathrm{g} \mathrm{L}^{-1}\right), 0.5 ; \mathrm{S}\left(\mathrm{g} \mathrm{L}^{-1}\right), 0.8 ; \mathrm{pH}$,

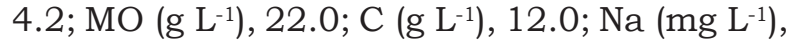
176.0; $\mathrm{Cu}\left(\mathrm{mg} \mathrm{L}^{-1}\right), 0.0$; Fe $\left(\mathrm{mg} \mathrm{L}^{-1}\right)$ 23.0; $\mathrm{Mn}\left(\mathrm{mg} \mathrm{L}^{-1}\right), 6.0 ; \mathrm{Zn}\left(\mathrm{mg} \mathrm{L}^{-1}\right), 1.0 ; \mathrm{C} / \mathrm{N}$ ratio ((C:N) or carbon-to-nitrogen ratio), 24; density, $1.0 \mathrm{t} \mathrm{m}^{-3}$; and surface tension $(\mathrm{mN}), 58.24$.

\section{Extraction of the available herbicide in the soil solution}

After the applications of herbicides, each soil sample was stirred in plastic bags for standardization of herbicides throughout the land portion exposed to the application. Aliquots of $4 \mathrm{~g}$ of each soil sample were placed in plastic cartridges with a total volume of $10 \mathrm{~mL}$, containing a porous polyethylene pad to retain soil particles, and coupled to a compartment for collecting the solution (Carbonari, 2009). Then the cartridges were saturated with deionized water or vinasse, according to each treatment. The amount of solution used was quantified for each cartridge according to soil texture, ranging from 0.8 to $1.2 \mathrm{~mL}$. Once saturated, the cartridges remained at rest for 18 hours, a period determined in previous tests to ensure 
the balance between the sorbed fraction and available in the soil solution.

For extraction of soil solution, the cartridges were centrifuged at $3,200 \mathrm{~g}$ at $15{ }^{\circ} \mathrm{C}$ for three minutes (Hettich Zentrifugen centrifuge). The solutions extracted from each cartridge were filtered in a membrane of PVDF $0.45 \mu \mathrm{m}$ (Millex-HV filter, $13.0 \mathrm{~mm}$ diameter) and packaged in $2.0 \mathrm{~mL}$ amber bottles.

\section{Total extraction of the herbicide remaining in the soil}

The cartridges containing the respective saturated soils subjected to the first extraction were stored in a freezer $\left(-20^{\circ} \mathrm{C}\right)$ and subsequently a second extraction of the herbicides was done in order to recover the remaining total herbicides sorbed in the soil. The determination of the extraction coefficients for each herbicide was done in a prior test (values of 74 to $82 \%$ ).

In the extraction, a system consisting in a hermetically sealed container was used, on which the cartridges were attached to the syringes containing an extracting compounding solution comprising calcium chloride and ethanol $\left(20: 80 \mathrm{v} \mathrm{v}^{-1}\right)$. By means of a vacuum pump connected to the container, the filtering cartridge took place by the extraction solution and the resulting content of this process was stored in falcon tubes. The solutions extracted from each cartridge were filtered in a membrane of PVDF $0.45 \mu \mathrm{m}$ (Millex-HV filter, $13.0 \mathrm{~mm}$ diameter) and packaged in $2.0 \mathrm{~mL}$ amber bottles.

\section{Quantification of herbicides}

The quantification of the herbicide concentrations in the solutions extracted for each soil sample was performed by liquid chromatography and mass spectrometry (LC-MS/MS), consisting of a high performance liquid chromatograph (Proeminence UFLC, Shimadzu Corporation), coupled to a triple quadrupole mass spectrometer (3200 Q TRAP, Applied Biosystems). A chromatographic column of C18 (Synergi 2,5 $\mu$ Hydro-RP 100Å, dimensions $50 \times 4.6 \mathrm{~mm}$ ), volume of injection of $20 \mu \mathrm{L}$ and as mobile phases, $0.5 \%$ acetic acid in water (phase A) and $0.5 \%$ acetic acid in methanol (phase B), with a flow of $0.5 \mathrm{~mL} \mathrm{~min}{ }^{-1}$ was used. The gradient used was: 0 minute, $50 \%$, phase $\mathrm{B}$; 1 minute, $95 \%$, phase B; 6 minutes, $50 \%$, phase B. The total running time for clomazone and tebuthiuron was 10 minutes, with retention in the chromatographic column of 6.46 and 6.91 minutes; analytical curves $y=1.93^{+004} x+1.38^{+004}$ and $y=2.41^{+004} x+9.88^{+003} ;$ and correlation coefficients $\mathrm{r}^{2} 0.9954$ and 0.9978 , respectively. The positive ionization mode by electrospray ionization (ESI) was used.

\section{Data analysis}

Using the data of herbicide concentrations in the soil solution, a linear regression adjustment was done among the various solutions used in soils saturation. The straight line intersection was defined as zero, so that the slope of the straight line allows to directly define in which solution the availability of each herbicide was higher.

Adding the masses of each of the herbicides in the two extractions and taking into account the extraction coefficient of each herbicide in the soil, it was possible to determine the amount of each herbicide in each soil cartridge and the percentage of availability of herbicides in each cartridge, considering each cartridge a repetition. The data were adjusted for the Gompertz model by means of the statistical software SAS (Statistical Analysis System) to represent the cumulative frequency $(F)$ of the availability in percentage of each tested herbicide, as proposed by Velini (1995):

$$
F=e^{\left[-s-a^{\left[-\infty c^{x} x\right.}\right]}
$$

The F-value represents the cumulative frequency of herbicide availability in percentage; $a$ is the maximum asymptote of the curve in which the value of 4.60517 was adopted; $e^{\mathrm{a}}=100$; the curve displacement along the axis $x$ is represented by the parameter $b$ module and the inclination or curve concave in relation to the cumulative frequency by the parameter $c$.

\section{RESULTS AND DISCUSSION}

Linear equations had a good adjustment, allowing the visualization of the differences 
of the interaction among treatments in various soil samples. Taking as a reference the equivalence line among the clomazone concentrations in both solutions compared, there was an average increase of $4.69 \%$ in the availability of clomazone in the solution of soils saturated with vinasse (Figure 1). Despite this increase in the availability of clomazone in the saturated soils with vinasse relative to the water, it is observed in general that most soils presented equivalent availability of this herbicide for water and vinasse; in only three soils did clomazone present the lowest availability for saturation with vinasse in comparison with water.

The availability of clomazone in the solution mainly depends on the clay and soil organic matter contents. Clomazone generally has a higher coefficient of sorption in clayey soils ( $\mathrm{K}_{\mathrm{d}}$ from 2.4 to 3.6), which contributes to reducing its availability in the soil solution. Do-Jin et al. (2004), analyzing four types of soils with different textures and organic matter content, have observed a higher concentration of clomazone in the solution in soils with less organic matter. Prata et al. (2001) have observed that the addition of vinasse in two soils with different characteristics (structured latosol and red-yellow oxisol) did not affect the sorption processes of ametryn herbicide.

The amount of tebuthiuron available in the soil solution averaged $17 \%$ higher than that of soils saturated with vinasse (Figure 2). In smaller herbicide concentrations found in the solution, between 10 and $25 \mathrm{mg} \mathrm{L}^{-1}$, there was no difference in the amount of tebuthiuron available in the soils saturated with deionized water or vinasse. However, for the higher concentrations of herbicide in the soil solution (30 and $65 \mathrm{~L}^{-1}$ ), the difference in the amount of tebuthiuron available in the soils saturated with vinasse was higher as compared to deionized water. Lourencetti et al. (2012) have observed an increase in the sorption of diuron in clayey and sandy soils with the addition of vinasse and, conversely, there was a significant reduction of sorption of tebuthiuron and hexazinone. These authors have also observed an acceleration in tebuthiuron degradation in both soils when vinasse was applied due to the increase in microbial activity.

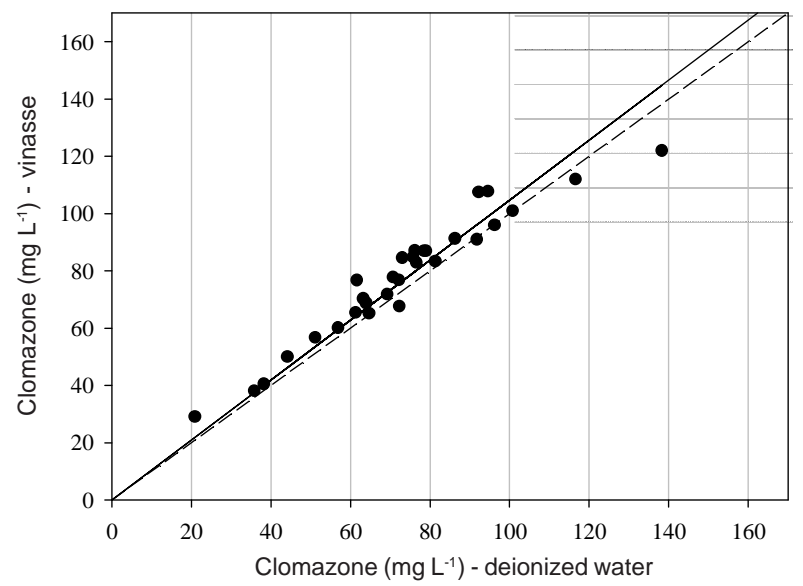

The solid line represents the linear regression among the different tested solutions, and the dotted line represents the equivalence between the concentrations of both solutions compared $(y=x)$. Regression equation $(\mathrm{y}=1.0231 \mathrm{x})$ and coefficient of determination $\left(\mathrm{R}^{2}=0.8321\right)$.

Figure 1 - Correlations between clomazone concentrations available in the soil solution ( $\mathrm{mg} \mathrm{L}^{-1}$ ) due to saturation with deionized water and vinasse.

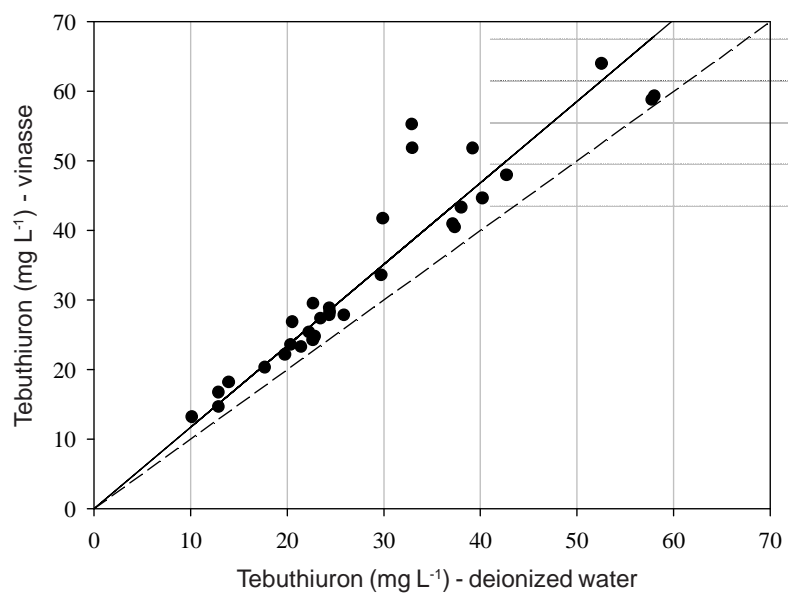

The solid line represents the linear regression among the different tested solutions, and the dotted line represents the equivalence between the concentrations of both solutions compared $(y=x)$. Regression equation $(\mathrm{y}=1.1672 \mathrm{x})$ and coefficient of determination $\left(\mathrm{R}^{2}=0.9521\right)$.

Figure 2 - Correlations between tebuthiuron concentrations available in the soil solution (mg L $\mathrm{m}^{-1}$ ) due to saturation with deionized water and vinasse.

The highest concentration of tebuthiuron in the solution of soils used in this study with the application of vinasse may be related to the considerable amounts of ions introduced to the soil with the incorporation of this 
residue (Ferreras et al., 2006; Fernández-Bayo et al., 2009). Silva et al. (2012) have observed that the addition of vinasse in clayey soil has increased the sorption capacity of potassium and, to a lesser intensity, sodium. Thus the increased retention of these ions to the soil can encourage competition between them and herbicidal molecules for adsorption sites available on the ground - this process tends to be enhanced in acid solutions due to competition between cations and ions $\mathrm{H}^{+}$ (Nicochelli et al., 2012). Spark \& Swift (2002) have found that fulvic acid applied to the soil competes for sorption sites between 2,4Dichlorophenoxyacetic acid and the soluble organic fraction, providing the herbicide in the soil solution.

The results of the regression analysis, coefficients for determination of the values of the cumulative frequencies (F) of the regression, as well as the constant values used in the model for the release of the herbicides in the soil samples and the cumulative frequencies are in Table 2. The major variations in the herbicides availabilities are associated with lower values for parameter "C" of the Gompertz model (Table 2).

Herbicide tebuthiuron presented the highest distribution averages of cumulative frequency of availability data for different soils (Table 2). On average, $32.49 \%$ of the total applied tebuthiuron was present in the soil solution, while for clomazone the value was $16.50 \%$.

The availability of clomazone in the soils ranged between 6 and 29\% of the total applied herbicide (Figure 3). The clomazone sorption capacity is variable according to the

Table 2 - Results of the mass regression analysis of each herbicide present in the extractions and cumulative frequencies, using the Gompertz model

\begin{tabular}{|l|r|r|r|}
\hline \multicolumn{2}{|c|}{ Model } & Clomazone & Tebuthiuron \\
\hline \multirow{3}{*}{ Values of the constants } & $\mathrm{A}$ & 4.60517 & 4.60517 \\
\cline { 2 - 4 } & $\mathrm{B}$ & -3.888901 & -3.315129 \\
\cline { 2 - 4 } & $\mathrm{C}$ & 0.264171 & 0.12058 \\
\hline Residual sum of squares (RSS) & 1343.66 & 612.22 \\
\hline F-test for Linear Regression & 96238.77 & 211383.13 \\
\hline $\mathrm{R}^{2}$ & 0.9942 & 0.9974 \\
\hline Mean & 16.503300 & 32.487857 \\
\hline
\end{tabular}

Planta Daninha, Viçosa-MG, v. 33, n. 4, p. 771-778, 2015

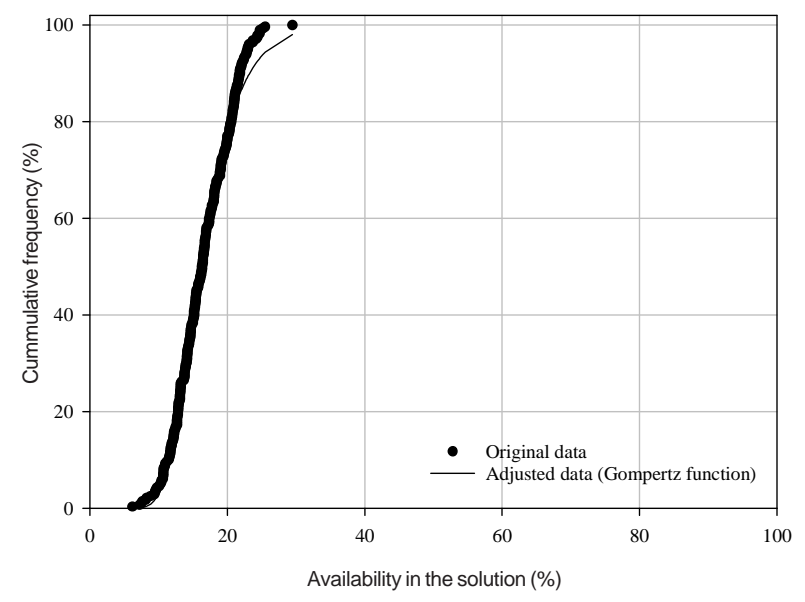

Figure 3 - Representation of the cumulative frequencies of clomazone availability in soil (\%) due to the soil saturation with water or vinasse.

type of soil (Mervosh et al., 1995). According to Li et al. (2005), greater sorption was observed in soils with higher clay content, cation exchange capacity and organic carbon. These characteristics favor the product retention on the surface of the colloids by hydrophobic bonds, hydrogen bonds and van der Waals forces, reducing the herbicide availability in the soil solution (Loux et al., 1989; Bollag et al., 1992).

The percentage of tebuthiuron availability ranged from 16 to $58 \%$ among the soil samples used (Figure 4). Souza et al. (2001) have observed that in Quartz-sand neosol the recovery of tebuthiuron in the solution was $10.2 \%$ of the total applied in the first $60 \mathrm{~cm}$

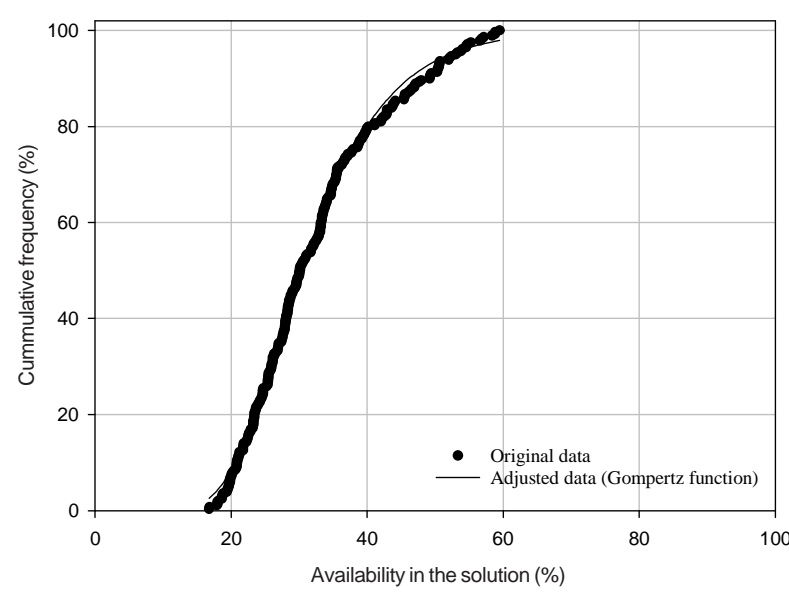

Figure 4 - Representation of the cumulative frequencies of tebuthiuron availability in soil (\%) due to the soil saturation with water or vinasse. 
deep in the soil column, showing that $89.8 \%$ of the total applied was retained on the column. In the Oxisol, there was a recovery of only $0.023 \%$, virtually any product remaining held in the first $20 \mathrm{~cm}$ of the column soil (98.96\%).

Chang \& Stritzke (1977) have reported that tebuthiuron had high availability and mobility in soils with low levels of organic matter and clay. These authors have found up to $40 \%$ of the adsorbed tebuthiuron when applied to the soil with higher organic matter $(4.8 \%)$, while in the soil with lower content $(0.3 \%)$ only one concentration of less than $1 \%$ of the herbicide was adsorbed.

Variations in the cumulative frequencies of the masses of available clomazone and tebuthiuron in different soils used in this study are due to associations of different factors, mainly those of the herbicidal properties, the inherent characteristics of the tested soils and saturation of these with vinasse or deionized water.

The vinasse was able to influence the sorption of herbicides in different types of soil, promoting the reduction of tebuthiuron sorption capacity and increasing its concentration in soil solution. However, the availability of clomazone was not changed due to the soil saturation with water or vinasse. Variations of availability and average availability of herbicides in different types of soil were higher for tebuthiuron, when compared with clomazone.

\section{LITERATURE CITED}

ARIAS-ESTÉVEZ, M. et al. The mobility and degradation of pesticides in soils and the pollution of groundwater resources. Agric. Ecosyst. Environ., v. 123, n. 4, p. 247-260, 2008.

BLANCO, F. M. G.; VELINI, E. D.; BATISTA FILHO, A. Persistência do herbicida sulfentrazone em solo cultivado com cana-de-açúcar. Bragantia, v. 69, n. 1, p. 71-75, 2010.

BENOIT, P. et al. Sorption and desorption of non-ionic herbicides onto particulate organic matter from surface soils under different land uses. Eur. J. Soil Sci., v. 59, n. 2, p. 178-189, 2008.

BENKE, M. B.; MERMUT, A. R.; SHARIATMADARI, H. Retention of dissolved organic carbono from vinasse by a tropical, kaolinite, and Fe-oxides. Geoderma, v. 91, n. 1-2, p. 47-63, 1999.
BOIVIN, A.; CHERRIER, R.; SCHIAVON, M. A comparison of five pesticides adsorption and desorption process in thirteen field soils. Chemosphere, v. 61, n. 5, p. 668-676, 2005.

BOLLAG, J. M.; MYERS, C. J.; MINARD, R. D. Biological and chemical interactions of pesticides with soil organic matter. Sci. Total Environ., v. 123-124, n. 3, p. 205-217, 1992.

BRASIL. Ministério da Agricultura, Pecuária e Abastecimento. AGROFIT. Brasília, DF: 2003. Disponível em: <http://agrofit.agricultura.gov.br/agrofit_cons/ principal_agrofit_cons>. Acesso em: 10 jan. 2015.

CARBONARI, C. A. Efeito da palha na disponibilidade do herbicida amicarbazone na solução do solo em áreas cultivadas com cana-de-açúcar. 2009. $101 \mathrm{f}$. Tese (Doutorado em Agronomia/ Proteção de Plantas) - Faculdade de Ciências Agronômicas, Universidade Estadual Paulista, Botucatu, 2009.

CHANG, S. S.; STRITZKE, J. J. Sorption, movement and dissipation of tebuthiuron in soils. Weed Sci., v. 25, n. 2, p.184-187, 1977.

DE JONGE, R. J.; BREURE, A. M.; VAN ANDEL, J. G. Reversibility of adsorption of aromatic compounds onto powdered activated carbon (PAC). Water Res., v. 30, n. 4, p. 883-892, 1996.

DO-JIN, L. et al. Soil characteristics and water potential effects on plant-available clomazone in rice. Weed Sci., v. 52, n. 2, p. 310-318, 2004.

EL-NAHHAL, Y.; ABADSA, M.; AFFIFI, S. Adsorption of diuron and linuron in Gaza soils. Am. J. Anal. Chem., v. 4, n. 7, p. 94-99, 2013.

FERNÁNDEZ-BAYO, J. D.; NOGALES, R.; ROMERO, E. Assessment of three vermicomposts as organic amendments used to enhance diuron sorption in soils with low organic carbono content. Eur. J. Soil Sci., v. 60, n. 6, p. 935-944, 2009.

FERRERAS, L. et al. Effect of organic amendments on some physical, chemical and biological properties in a horticultural soil. Biores. Technol., v. 97, n. 4, p. 635-640, 2006.

HELBERT, S. Behaviour of four soil-active herbicides in a boreal podzol. For. Ecol. Manage., v. 31, n. 3, p. 125-152, 1990.

LI, K.; XING, B.; TORELLO, W. A. Effect of organic fertilizers derived dissolved organic matter on pesticide sorption and leaching. Environ. Poll., v. 134, n. 2, p. 187-194, 2005. 
LOURENCETTI. C.; MARCHI, M. R. R.; RIBEIRO, M. L. Influence of sugarcane vinasse on the sorption and degradation of herbicides in soil under controlled conditions. J. Environ.

Sci. Health - Part B, v. 47, n. 10, p. 949-958, 2012.

LOUX, M. M.; LIEBL, R. A.; SLIFE, F. W. Adsorption of clomazone on soils, sediments, and clays. Weed Sci., v. 37, n. 3, p. 440-444, 1989.

MATALLO, M. B. et al. Sorption, degradation, and leaching of tebuthiuron and diuron in soil columns. J. Environ. Sci. Health - Part B, v. 40, n. 1, p. 39-43, 2005.

MERVOSH, T. L.; SIMS, G. K.; STOLLER, E. W. Clomazone fate in soil as affected by microbial activity, temperature, and soil moisture. J. Agric. Food Chem., v. 43, n. 2, p. 537-543, 1995.

NICOCHELLI, L. M. et al. Sorção de potássio em amostras de solo submetidas à aplicação de vinhaça. R. Bras. Eng. Agríc. Amb., v. 16, n. 7, p. 754-760, 2012.

PARNAUDEAU, V. et al. Vinasse organic matter quality and mineralization potential, as influenced by raw material, fermentation and concentration process. Biores. Technol., v. 99, n. 6, p. 1553-1562, 2008.

PRATA, F. et al. Degradação e sorção de ametrina em dois solos com a aplicação de vinhaça. Pesq. Agropec. Bras., v. 36, n. 7, p. 975-981, 2001.

RODRIGUES, B. N.; ALMEIDA, F. S. Guia de herbicidas. 6.ed. Londrina: Grafmarke, 2011. 696 p.
SILVA, N. F. et al. Distribuição de solutos em colunas de solo com vinhaça. Irriga, v. 1, n. 1, p. 340-350, 2012.

SOUZA, M. D. et al. Adsorção e lixiviação de tebuthiuron em três tipos de solo. R. Bras. Ci. Solo, v. 25, n. 4, p. 10531061, 2001.

SPADOTTO, C. A.; MATALLO, M. B.; GOMES, M. A. F. Sorção do herbicida 2,4-D em solos brasileiros. Pestic. R. Ecotoxicol. Meio Amb., v. 13, n. 1, p. 103-110, 2003.

SPARK, K. M.; SWIFT, R. S. Effect of soil composition and dissolved organic matter on pesticide sorption. Sci. Total Environ., v. 298, n. 1-3, p. 147-161, 2002.

TIAN, C.; WANG, M. D.; SI, Y. B. Influences of charcoal amendment on adsorption-desorption of isoproturon in soils. Agric. Sci. China, v. 9, n. 2, p. 257-265, 2010.

TOMCO, P. L. et al. Microbial degradation of clomazone under simulated California rice field conditions. J. Agric. Food Chem., v. 58, n. 6, p. 3674-3680, 2010.

TONIETO, T. A. P.; REGITANO, J. B. Effects of straw decomposition degree on leaching and weed control efficacy of tebuthiuron and hexazinone in green sugarcane harvesting. Planta Daninha, v. 32, n. 4, p. 809-815, 2014.

VELINI, E. D. Estudos e desenvolvimento de métodos experimentais e amostrais adaptados à matologia. 1995. 250 f. Tese (Doutorado em Agronomia/Produção Vegetal) Universidade Estadual Paulista Júlio de Mesquita Filho, Jaboticabal, 1995. 